\title{
The Impact of the Domestic Environment in the Change of Foreign Policy- The Case of Russian Policy towards the European Union after the End of the Cold War
}

\author{
Hossam Nabil Salaheldin Moshref ${ }^{1}$ \\ ${ }^{1}$ Faculty of Economics and Political Science, Cairo University, Giza, Egypt \\ Correspondence: Hossam Nabil Salaheldin Moshref, Faculty of Economics and Political Science, Cairo University, \\ Giza, Egypt. Tel: 20-10-0241-8396. E-mail: hossam_nabil2015@feps.edu.eg
}

Received: June 6, 2020

Accepted: July 16, 2020

Online Published: August 17, 2020

doi:10.5539/jpl.v13n3p43

URL: https://doi.org/10.5539/jpl.v13n3p43

\begin{abstract}
Purpose - This paper aims to study the impact of the domestic environment's components in changing foreign policy. Therefore, the paper focuses on analyzing Russia's strategies, in the International arena, that has been structured by the domestic factors (leadership, military, security, economics, and identity).

Design/methodology/approach - The paper follows three theories of studying the impact of domestic components into foreign policy in international relations; First it focuses on Foreign Policy Analysis as a traditional analysis in international relations; depending on "Determinants" influencing the foreign policy and the "Instruments/Tools" used to achieve the goals of foreign policy. Second, Neo-Classical Realism Theory, as it tried to explain the importance of internal factors in the foreign policy. Third, Constructivism Theory in International Relations as it concerns Non-state actors and refused the traditional viewing of main concepts in international relations.
\end{abstract}

Findings - The domestic environment is the background context on which foreign policy is drawn. In general, the domestic environment is within the framework of society; according to it the decision-makers make decisions and include domestic policies (public opinion, geographical location, nature of the political system, main values of society, parties, lobbies...etc.); national expertise can be added in dealing with international political issues.

Originality/Value - This paper proves that there are new forms for foreign policy variables related to the domestic environment and reflects the Economic capabilities, Military Power, Identity, and Leadership into the state's foreign policy.

Keywords: foreign policy, domestic environment, Russia, European Union, constructivism, decision-making, internal, external, determinants

\section{Introduction}

Traditional foreign policy analysis has traditionally been the main foreign policy actor and the main analysis unit has the capability of influential external action, despite the development of international relations and the emergence of actors from non-state actors with an effective influence and an integrated program of conduct in the international system.

Foreign policy has begun to be the sum of official foreign relations conducted by an independent actor in international relations. Discussing an "independent actor" gives the way for foreign policy to study actors from countries such as the Russian Federation towards non-state actors such as the EU, which was evident among foreign policy theorists beginning at the end of the 1960s (Hill, 2003, p.3).

Many studies have found that the foreign policy of an actor from countries such as Russia is being studied towards an independent non-state actor such as the EU through the foreign policy analysis platform, where it can respond, make and implement a foreign policy to achieve its objectives using different tools. This is not limited to the EU's "common foreign and security policy" but also the external aspects of the various areas of the EU's competence from economic policy to justice and internal affairs. (White, 1999, pp. 37-66).

In general, foreign policy analysis sets a framework for scientific analysis of the foreign policy phenomenon, in terms of describing its various dimensions such as general trends and objectives. In addition to interpreting them 
by identifying the range of variables affecting them and analyzing the relative impact of those variables on policy, as well as study foreign policy decision-making.

As for the general framework provided by the foreign policy analysis of the foreign policy of the actor is to study the determinants., i.e. variables that affect foreign policy and can be classified into external determinants, which arise from the external environment, both international and regional i.e. coming from outside the scope of the international actor's practice, and internal determinants that emanate from the international actor itself, are linked to its own and structural composition. (Selim, 1998, pp. 137-138).

Foreign policy can be explained by determining the relative weight of different foreign policy determinants in determining the shape of foreign policy that depends on the policy-makers perception of these determinants. (Selim, 1998, pp. 433-435).

The foreign policy maker's understanding of the determinants affects foreign policy results in policies where the tools used to achieve foreign policy objectives are multiplied, it can be categorized into four groups: (diplomatic tools, military tools, economic instruments, and cultural tools) and indirect tools to change the internal environment of the target actor of politics. (Hill, 2003, pp. 138-154).

Based on the aforementioned, the study aims to analyze the role of internal variables in influencing foreign policy, which has been illustrated by the components of the domestic environment influencing Russian foreign policymaking towards the European Union.

\section{Accordingly, this paper is divided into two main parts:}

The first part will serve as a framework and theoretical entry to the study, that will address the presentation of the discussion and theoretical debate on the issue of separation and linking between the internal environment and the foreign policy of states in terms of impact, while the realistic approach goes to separate the inside from the outside and deny any impact of the environmental data. Another team believes that the situation of the environment, internal politics, and the foreign policy of states should be linked to provide an acceptable and integrated interpretation of the transformation of the behaviors of states towards their external environment, likewise the constructivism theory that refuses to separate the environment.

Internal and international in the analysis of the behavior of political factors, and this is evident in its rejection of the classical concept of interest among the realists, the interest stems not only from the nature of the international community but also from the nature of the value and social construction of political units, because the interest is no longer determined by the constructivism, it is determined outside the context of the actors and isolated within the international system, as a pre-given dictated by the structure of the anarchist international order.

1) The second part means the role and influence of the transformations and the various variables that make up the Russian internal environment on the nature of its external relations with the European Union between the direction of cooperation, confrontation, and conflict; where it will address the nature of these transformations that Russia has experienced since the end of the Cold War, and then the decision making an environment in Russia and highlight the role of internal factors influencing the nature of the external decision, as the latter includes all the influential forces in the Russian political arena from the state organs, parliament, political elites, parties, and public opinion. The shift in the distribution of power between these components will have a direct and significant impact on Russia's external orientation towards its relationship with the European Union, in the context of cooperative or conflict interactions, and prioritize its foreign policy.

\section{Realism Theory and Foreign Policy Analysis Approach}

Realism (classical realism, neorealism, neoclassical realism) has tried to provide acceptable explanations of what is happening in international relations, and the common denominator between them is confirming the impact of the international environment on the behaviors of external factors, but what can be observed concerning the nature of the separation between the domestic and foreign policy is the difference in the intensity of this separation, so that there is a total separation among the proponents of traditional realism, while the proponents of neoclassical realism go to mitigate the intensity of this separation and agree with the impact of the domestic determinants of the state and its importance in understanding the external behavior side by side with external determinants.

\subsection{The Importance of the Domestic Environment in Neoclassical Realism in the Interpretation of Foreign Policy}

After the total denial of the interference of domestic environment in the interpretation of foreign policy, "Neoclassical realism" attempted to reduce the separation of the domestic and external environments, presenting 
moderate explanations forming a positive initiative to review the levels of analysis adopted in the interpretation of external behavior and give importance to domestic determinants.

Neoclassical realism is also divided into what is known as Defensive realism and Offensive realism, both of them recognize the role and influence of the domestic environment and the perceptions of decision-makers on foreign policy orientations and objectives, but this does not prevent differences between them.

\subsection{Defensive Realism}

Defensive realism assumes that the anarchism of the international system is less dangerous and that security is available rather than missing, and in so doing it offers a theoretical concession by reducing international coordinated incentives, making them not controlling the behaviors of all states, and recognizes the existence of distinct foreign policies, thus recognizing the minimal effects for the domestic environment on external behavior (Rose, 1998, pp. 146-149).

Defensive realism has developed its hypotheses to show the impact of the domestic environment of the state in determining the nature of the external orientation of states, in case of an external threat, the state is recruiting the military, economic and human capabilities, and the awareness of this danger is linked to the personality of political leaders, who limit the means used to defend only vital interests, and the greatest vital interest is security.

\subsection{Offensive Realism}

Offensive realism emerged as a reaction to the defensive realism, it criticized the latter for its main assumption that it is, the state within the framework of international chaos is only looking for its security, where it sees the opposite is chaos usually imposed on states to maximize and increase power, so they believe that the possibility of war between countries increases whenever some of them can invade another country easily, therefore the continuing of absolute chaos (Walt, 1998, p.31).

But what distinguishes this proposition is the failure to recognize that the interpretation of foreign policies and the international outputs of different countries is based on the idea of chaos, which is rejected by offensive realism as a single factor, the focus on the foreign policy of states must include domestic environment's variables and other specific aspects of international policy that can be explained by these variables (Mearsheimer, 2000, p.1).

These new attitudes to neoclassical realism have a profound transformation to Realism school with the regard to the boundaries between what is internal and external, giving the way for the need to reconsider the impact of domestic determinants in the direction of foreign policy, and to remove that division between them.

All of this posed the problem of the explanatory ability of approaches that tried to explain external behavior by returning to the structure of the international system, even according to realists, led by Christensen, who said: "The realism legacy can have an interpretive ability at a specific time", but some new assumptions can be explained by domestic policy theories, such as ideological differences, domestic political pressures, or even the psychology of different leaders, this has led to the emergence of theoretical models that consider various domestic variables in the understanding and interpretation of external behavior. (Rose, 1998, p.156).

\section{Constructivism Theory in International Relations}

Theories such as realism, neoliberalism have contributed significantly to the study of international relations, but the years followed the end of the cold war have seen the emergence of many new currents that have criticized theories of realism and neoliberalism and presented many questions about the epistemological and anthropological assumptions of these theories, these are known as critical or post-positivism.

\subsection{Basic Assumptions of Constructivism Theory (Viotti, 2012, p.278)}

Constructivism has a different explanation for basic concepts in international relations such as national interest, identity, and national security, as constructivists refuse to accept these concepts as they are given.

Constructivists' main concern is non-state actors such as international organizations and non-governmental organizations.

Moreover, constructivism focuses on the knowledge and cognitive variables that result from the interaction of these units in their relations.

Constructivism considers the structure of the international system as a social structure that includes a set of values, rules, and laws, which affect the identity and interest of the actors.

Constructivism, as its name suggests, describes the international system as a permanent and ongoing process of constructing between the interaction of the actors and the construction. 
For constructivism, the world is always a renewed issue, not something that has been done and must be accepted as it is. This, of course, is a different position from that of realists, liberals, and even radicals with their concerns about the international system.

Constructivism theory has made serious contributions to dialogue and anthropological debate in international relations by rejecting assumptions that assume laws are controlling social and political phenomena that don't care about the will of the actor and his ability to influence his surroundings.

Constructivism defines the concept of "Rule" in the sense of linkage mediator, which connects the person with society. The rule for constructivism is the phrase that teaches us what to do, what should we do, and here's what constitutes the standard, the scale, or the model that people should do in similar circumstances (Onuf, 1998, p.59).

In brief, Constructivism as a theory in international relations trying to find the relation of the link between the three components of international relations i.e. actor, system, and the process of interaction between them.

The nature of the post-Cold War era formulated suitable environment for testing constructivism theory, which many thinkers such as Barry Buzan and Richard Little consider it as a provider for an appropriate entry point for understanding and studying international relations at an era where the role of identity and social variables has increased in a globalized system and civil wars. Therefore, this theory highly accepted by academics and politicians.

With applying constructivism, the variables of Russia's domestic environment consist of several different elements, and to analyze the relationship between these units that make up the domestic decision-making environment within the framework of the prevailing social, political and economic pattern within Russia and its integrated structures in the framework of Russian society, therefore, the constructivism helps to explain each component, so that each variable is related to other variables so that constructivism's analysis method concerns about fundamental realities.

\section{Types of Change in Foreign Policy}

Charles Hermann distinguished between four types of change in foreign policy that represented progressive levels of change:(Hermann, 1990, pp.4-5)

1) Adjustment Changes: Change occurs at the level of interest, more or less, or at the level of the receivers (reidentifying the targets) but within the same objectives and tools.

2) Program Changes: Change in tools but within the same goals, unlike adaptive change where it is quantitative and includes tools.

3) Goal Changes: a change in foreign policy objectives, not just a change in tools.

4) International Orientation Changes: The most extreme type, unlike previous cases where change towards specific issues or actors, the change in foreign policy orientation includes most aspects of the actor's role at the international level.

\section{Reasons for Foreign Policy Change}

There have been several studies that have explained the change in foreign policy. Some of them has adopted that the change in foreign policy results from changes in the external environment, both international and regional, while another group has adopted that it results from changes in the domestic environment, while a third group adopted the combination of external and domestic variables as reasons to change foreign policy.

\subsection{External Variables}

Variables at the international system level (single, bipolar or multipolar system) or regional variables that require the state to be adapted to it by making changes to its foreign policy to adapt to the variables of the external environment at both regional and international levels.

One of the most important contributions that focused on the role of external variables in influencing change in foreign policy was the Skidmore model (Skidmore, 1994, pp. 43-61), which created a model of change in foreign policy by combining the hierarchy of the international and domestic power of the State, assuming the need for a response of States for the changes dictated by the international environment, and the international distribution of power and interests.

The model is based on assumptions of realism and institutionalism where each seeks to interpret foreign policy, but from different points of view, in other words how the change occurs? Where the theory of realism assumes that the state is moving in response to changes dictated by the external environment, while the institutionalism emphasizes stability and the limited ability of a State to respond to international changes. 
Skidmore aims to analyze the circumstances that lead to the dominance of one of the two previous directions over the other, which is embodied by the work of a bilateral classification that combines the power of the state at the international level and the community level which means the power of the state towards other states and entities, as opposed to the power of the state towards domestic society, where change occurs when the state is powerful at the international level and weak internally, in such case the state can ignore external pressures while unable to resist domestic interests calling for stability.

Evolutionary change, on the other hand, occurs if the state enjoys a strong domestic status and weak internationally which makes the state more sensitive to international pressures and being able to ignore domestic preferences and interests. Skidmore, therefore, suggests that international controls and restrictions may require a change in foreign policy in a specific direction.

\subsection{Domestic Variables}

Assuming that variables such as the system of the state, its relation with society, its identity, as well as the decisionmaking process and bureaucratic policy, internal competition for power and government change, the emergence of opposition movements, the ideology and legitimacy of the political system, and internal stability affect the state's foreign policy and so a change in these variables will lead to a change in foreign policy (Elsheikh, 2000, p.13).

\subsection{Combining External and Domestic Variables}

Some cultures have combined external and domestic variables to explain the change in foreign policy, such as:

\subsection{Holsti's Foreign Policy Restructuring Model}

Holsti focused on the pattern of state foreign policy restructuring that occurs in a longer period than regular or gradual changes. He developed a theoretical framework for interpreting this shift based on the independent variables affecting foreign policy as follows: external factors (military and non-military threats, interdependence), domestic factors (internal threats from riots and civil wars, and exposure economic, parties and interest groups), historical and cultural factors. In addition to intermediate variables such as cognition, personality, elite orientations, and the policy-making process (Holsti, 1982, p.4).

Holsti outlined four basic foreign policy directions: isolation, self-reliance, dependency, and non-alignment or diversification. He saw restructuring as a shift from one direction to another by the influence of the four explanatory variables.

\subsection{Goldmann's Study of Foreign Policy Change and Stability}

Goldmann has created an integrated model of foreign policy change and continuity by analyzing "stabilizing factors" of foreign policy, starting from identifying three sources of foreign policy change: change in the environment, negative feedback, and change of decision-maker.

According to Goldmann, these factors do not prompt a direct change in foreign policy, as there is sometimes pressure for no change. Therefore, the problem has crystallized around the study of the factors of the continuation of foreign policy in the presence of reasons for change, hence the intermediate variables called stability factors representing an intermediate variable that determines whether the foreign policy will interfere in the process of change in response to sources change and how far the degree of change will be.

Goldmann has defined "stability factors" as a feature of the policy, ideas behind it or the actor, or the relationship between the actor and the environment that can minimize the impact of causes of change. Assuming that in the absence of stability factors, foreign policy is more sensitive to change in the surrounding environment or to negative feedback, but stability factors reduce this sensitivity and may lead only to reduce or delay policy change.

This definition may help to combine many factors rather than narrow classification. Goldmann classified stability factors into four groups as follows: administrative factors, political factors, perceptions factors, and international factors. The first three groups are stabilizing factors of an internal nature that focus on the beliefs of decisionmakers, domestic institutions and the legitimacy of the system, the nature of the bureaucracy, and the structure of decision-making.

Goldmann elaborated on these factors and their role in the continuation and stability of foreign policy and the impact of the factors leading to change (Goldmann, 1988, pp.4-6). The main contribution of Goldmann's theory is therefore to compare the powers of continuity (stabilizing factors) and change (environmental change and change in leadership) by using thirteen administrative, perceptive, political, and international variables to explain the stability of foreign policy. 


\subsection{Charles Hermann's Foreign Policy Redirection Model}

Herrmann proposed four independent variables leading to change in foreign policy, three of them are domestic, they're: the leadership initiative (that means imposing the current leadership its vision of reorienting foreign policy), and support of the government (in the presence of a group Within a body or several government agencies supporting and pushing for change, which must be related to senior officials to increase their effectiveness in change, internal restructuring (returning to the political segment expressing society and supporting the need for change), and finally external shocks (that occurs because of the changes caused by major events at the international level which is being realized by the current government, because of its urgent and rapid impact, the state must respond to it and change its policy).

Herrmann assumes that governments change their policy through the decision-making process that mediates the factors that lead to change or not, and affects the level of change occurring, whether they are in the program, objectives or the international orientation as a whole and this process may facilitate or inhibit change, dividing it into seven stages from the awareness of the problem under the actual policy to the implementation of the new policy (Hermann, 1990, pp.4-5).

\section{Concepts of Internal Variables}

Democracy, it can be treated as an ideology, concept, or theory. Democracy is an ideology embodying a set of political ideas that reflect the best possible form of social organization, as well as a political concept that reflects some form of governance or actions taken to establish the government.

Good governance, governance itself is a neutral concept, reflecting the act of political system and its management of community affairs, resources, economic and social development. It includes, in addition to the work of official state bodies, the work of both civil society organizations and the private sector.

The concept, therefore, reflects the processes of exercising power to achieve development goals.

The concept of national interest, if states differ in the general directions under the determination of their foreign obligations, they all converge at the final goal which is the national interest.

The concept of national interest is one of the main concepts in the realistic analysis of international policy. The realism theory, classical and post-classical considers the interest is an objective and self-contained reality, regardless of whether it is perceived or not understood by decision-makers.

It is the focus of and all of the international relations concepts launches from, since its emergence as a tool of political analysis to describe, interpret and evaluate the foreign policies of states, it has been used to justify, reject or propose certain political behavior.

Hans Morgenthau, one of the realism school's most vocal advocates of this concept, he has tried in his writings to provide the most comprehensive definition of the national interest within the framework of the realism school. In his book Politics Among Nations, Morgenthau considers the national interest as the permanent measure on which political action can be guided and evaluated. (Morgenthau, 1985, p.57).

The constructivist theory suggested a more dynamic and forward-moving analysis of the concept of national interest, paying full attention to the definition of identity in the process of shaping national interests, and on the idea that the national interest could change as the definition of identity evolves.

This analysis is also based mainly on the recognition of a feedback process between interests and identity, both of which play a valuable reciprocal role for each other (McSweeney, 2000, p.126).

Thus, foreign policy, based on how decision-makers explain the national interest, is directly linked to the concept of national identity, an idea that Samuel Huntington argues in one of his articles: "The national interest requires its harmony with the nature of the state in which its definition of the national interest coming from its national identity" (Huntington, 1997, p.28).

Zero-sum game theory is one of the important strategic theories for decision-making in situations of conflict or international conflicts, its goal is to rationalize the choice of different alternatives produced by conflict situations, and address all conflicts of interest, whether it is political conflict in general or conflicts which relates to peace and war in particular.

Martin Schobeck defined it as a "mathematical way of studying some aspects of the decision-making process, particularly in situations dominated by conflict or cooperation", the essence of the game theory is the assumption that there is a group of decision-makers whose goals overlap and which they seek to achieve, with each of them having some partial or limited control over the situation they all deal with. 
This theory not only assumes that one side wins the loss of the other, but the game may ends with relative cooperation between the two sides so that the absolute loss is avoided (Mkld, 1991, pp.36-37).

\section{Domestic Environment Variables Affecting the Foreign Policy of Countries}

The approaches that tried to quantify the domestic environment affecting foreign policy are different, but it seems that some of the approaches presented especially in the context of the comparative foreign policy, presented the sum of these variables in a detailed form, so that in this context, the model of "Patrik Macfon" and "Howard Shapero", whose provided a comprehensive foreign policy comparative analysis framework in terms of its integration of the various elements influencing foreign policymaking, contains nine out of twelve domestic factors, reflecting the significant importance of the relative weight of these variables in the interpretation of external behavior.

\subsection{Components of the Domestic Environment}

\subsubsection{The Relation between the Type of the Political System and the Foreign Policy}

To be able to know the weight of internal variables, and which of them emerges and declines according to the type of the political system of the state, which determines the nature of the variables affecting external behavior.

Individual variables were believed, from a realistic perspective, that politicians were rational because they thought from interests defined by the concept of power and accepting the assumption denoting the deep searching into the motivations of the individual or group was a waste of time.

The assumption of rationality has been criticized for many years and many studies began during the 1970s that go beyond the state and examine the aspects associated with the individuals themselves and groups as influence factors in foreign policy behavior.

Individual or personal variables according to "Shapero" and "Macfon" include the personal characteristics of the individuals who make foreign policy, as well as the "set of self-motivation and personal characteristics of a political leader or political leaders who make foreign policy" (Selim, 1998, p.137).

These characteristics include their beliefs, values, experience, qualities, social composition, as well as their awareness (Yousef, 1985, p.20).

The impact of personal variables on foreign policymaking varies depending on the conditions in which foreign policy is made.

Elite variables, the political elite is a group of individuals who have the resources and tools of authority in society, and these groups include the leaders of the executive and legislative branches, political parties and the military (Selim, 1998, p.187).

It is also known as "a descriptive term for individuals and groups at a top of particular hierarchical" (Evans, and Newnham, 1998, p.200) that contains the general features of the elite that make foreign policy, the age rate, the level of knowledge, experience and specialization, the proportion of civilians and military personnel (Yousef, 1985, p.202).

The foreign policy elite is divided between the incumbent of official positions and organized interests - what Almond defines the political elite - the incumbent's control positions of authority within the system and are the persons officially concerned to act on behalf of the state, surrounded by a bureaucracy of departments distributed around foreign ministries but also include several other state ministries (Evans, and Newnham, 1998, p.201).

The influence of the political elite depends on the form of the political system, the homogeneity of the political elite, and agreement on the basic lines of foreign policy. (Selim, 1998, p.188).

Political variables, the characteristics of public policy effectiveness in terms of the nature of informal political actors and how they affect the political process of the state, including the party system in the state, the roles played by parties and interest groups, public opinion and the media, the level of political development in the state, and the pattern of domestic political conflicts (Yousef, 1985, p.203).

In this context, the most important of these factors affecting external behavior can be limited to the following:

Political parties, some scholars of foreign policy considers political parties that have representatives in the executive branch can influence the outputs of the foreign policy, and this, especially in democratic systems.

Also, the form of political party life in the state, one-party system, or bipartisanship or multi-party system determines the circumstances of their influence on the foreign policy decision making. 
Interest groups, are groups of individuals with a common interest, and these groups may be in the form of 'unorganized interest groups' such as ethnic, religious or linguistic minorities whose members share the common interest of ethnic, religious or linguistic affiliation, and these groups may be characterized by such organizations as with an organizational entity and systems for internal and external communication.

The most important forms are trade unions, businessmen, unions, engineers, doctors, and lawyers syndicates. (Selim, 1998, pp.196-197).

Interest groups try to influence foreign policy decisions that are appropriate to the nature of their composition and interests, although interest groups may sometimes act like political parties by entering elections through their candidates, their foreign policy activities are often limited to trying to influence the legislative and executive branches.

The influence of interest groups is often very limited on foreign policy, as they are unable to hold senior positions within decision-making positions, which leads them to convince those in the power of the validity of their demands, which is difficult to achieve, especially at the high-level policies related to security and military policies.

Their impact is also weakened when they are in a situation where the interests of many groups collide and end up with a terminal paralysis of their influence on foreign policy decisions.

Public opinion, the role of public opinion is relatively limited to influencing foreign policymaking, but it is constantly increasing due to several factors, including the role of social media on the internet, but it always exists in different levels depending on the nature of the state, and therefore forms controls on the foreign policy-making and varies in influence from one case to another (Yousef, 1985, p.203).

Studies indicate that public opinion often lacks the accurate and correct information required to make external decisions, and this is relatively lost influence on external decisions affecting sensitive issues, and this opens the way for decision-makers to have a significant impact because they have sufficient information, and the ability to convince public opinion of their views, through targeted means of communication, happens even within the most open countries such as the United States of America and its ability to convince the American public opinion about the war in Afghanistan in 2001, and Iraq in 2003.

Community variables include some aspects of the social structure in general, such as population volume, population growth rate, level of social development, and patterns of social progression. (Yousef, 1985, p.205).

This proposition argues that decision-makers are the product of their societies and are based on postmodernism theories, so the environment to which these people belong affects them so much that societal variables represent the sum of the prevailing values, ideas, speeches and social cultures within the community, this is the valuable criterion for accepting or not accepting decisions following the social legitimacy derived from these components because they are not merely temporary casual positions but are characterized by relative stability, making them a source of legitimacy or illegality of the external behaviors of states.

That's why societal attitudes play a big role in determining the course of external behavior, it is defined as "the set of political ideas that most members of society embrace, which define their vision of the political world. (Selim, 1998, p.202).

Cultural variables, Macfon and Shapero differentiate between cultural and social variables in their model, but many scholars did not differentiate between them, as cultural variables came in the context of the community of nations and due to the great overlap between them.

These variables, according to Macron and Shapero, include cultural systems in national societies such as multiculturalism, national identification, different communication patterns, and beliefs of society and their ability to be a popular mobilization tool.

The distribution of cultural values within society affects foreign policymaking through the identity of actors, their objectives, the cultural characteristics of peoples, the quality of intellectual and ideological affiliations, and loyalties. (Selim, 1998, p.258).

The Economic variables, that contain the economic structure, balance of payments, trade balance, level of economic development of the state, quantity of its foreign trade (Yousef, 1985, p.209).

These variables affect the output of foreign policy decisions, as the country has been economically developed as the greater the level of its interaction in the international system with other actors, and increased opportunities for cooperation more than the possibility of engaging in conflict behaviors and this is what the neoliberalism went to through the approach of democratic peace so that we find homogeneous societies in the form of a capitalist economic system, behave cooperative and integrative behaviors. 
In general, economic factors play a main role in foreign policy choices, because the implementation of most policies requires the availability of economic resources (Jensen, 1982, p.185).

Therefore, the situation of internal stability and high levels of economic development gives the state the ability to negotiate and bargain in its foreign policy, especially if it can produce and possess strategic security goods in its relations with other countries, and in the case of Russian-European relations, energy is considered a sensitive resource in this relationship.

The connectivity variables, is the meaning of the linkage between the former foreign policy of the state and the current foreign policy, as well, the perception of decision-makers of a particular state according to its prior provisions determines the nature of its policy towards it, the existence of agreements between the two countries contributes to the reduction or absence of conflicting behaviors between them, as well as the existence of a certain level of previous cooperation between the two countries later influences their foreign policy towards each other.

It is clear from viewing these internal variables the extent and magnitude of their impact on the external behavior of states, but comparative foreign policy studies confirming the relative weight of these variables are different in effect from one country to another, so that in the analysis of the behavior of external states sometimes the rise of other variables and descent of another, the sequence of the elements of influence is in terms of their weight in different situations, and this is determined by the nature of the political system and the form of the relationship between the governmental institutions within each state, which determines the nature of the variables that are increasingly influential and other variables that are declining or missing permanently.

In addition to being influenced by previous variables, foreign policy must be created within a particular political structure that affects it, because national beliefs, social and economic conditions, and individual decision-making characteristics affect the formulation of foreign policy objectives. To achieve those objectives as priorities in this policy, decisions must be based on the selection of certain options, and here the way decisions are made and the quality of their making affect the content of these choices.

Governmental variables and the form of the political system, these variables related to the influence of the form of the political system on the nature of foreign policy decision, so these variables include the structural features of the political system such as the form of government (democratic/authoritarian) and the level of military capabilities.

There are now two basic assumptions that democracies are part of the wisdom of traditional international relations.

First, democracies are more peace-loving than other types of political systems, and they rarely, or never, fight each other, according to Kant's theory, or the theory of "democratic peace".

Second, democracies are weak in the formulation and implementation of foreign policy, according to the theory of "de Tocqueville" (Evans, and Newnham, 1998, pp.164-165).

Through the "theory of democratic peace", neoliberalism attempted to begin to analyze the relationship between the type of political regime's authority and foreign policy.

Therefore, in this regard, there are two types of regimes, open democracies and closed authoritarian regimes, the type of regime that determines which of the above-mentioned variables will affect foreign policy decision making. Therefore, the need for a comprehensive program of action is needed to ensure that the most vulnerable countries can meet their demands.

But this proposition has been heavily criticized, particularly at the point where critics assert that democracies are only consulted on issues of lower policy, while when it comes to security or sensitive political issues, they make decisions in a closed office.

On the second point, the ineffectiveness of democracies in the formulation and implementation of foreign policy; analysts believe that authoritarian regimes have many advantages that allowing for highly effective decisions at the external level when compared to those in democratic regimes.

According to the theory of "de Tocqueville", democracies are slow to respond to external issues, especially in the time of crises, and when they respond, the response may be extreme.

The reason for this situation -according to de Tocqueville's view- is the interference of domestic policy in foreign policymaking and the constant need to respond to public opinion.

On the contrary, fascist regimes have an advantage because of a closed political system stable, unfettered and not constrained by the need to return to the public opinion and that enabling them to make quick decisions and have great resilience (Evans, and Newnham, 1998, p.165). 
The failure in dealing with public opinion and variety of social or political groups not only will be in situations that require a quick response, but this separation from internal pressures affects even foreign policy issues in the medium or long terms, such as the stability in the characteristic of a country's foreign policy towards another state, or the lack of influence of internal changes and pressures on the directions of the foreign policy of the state towards other countries.

Trends of convergence and cooperation or divergence and conflict in Russia's relationship with the European Union countries are not determined by the different components of the Russian domestic social, political and economic environment, as determined by the desire of the political leader who directs power.

Institutional variables, in addition to the variable related to the form of the political system, the composition of institutional variables play an important role in determining who makes and directs decisions, including the number and type of departments and authorities involved in the foreign policymaking process, the level of bureaucratic modernization of these departments and authorities, how roles and powers are distributed between them, as well as the available tools to influence the foreign policy-making (Yousef, 1985, p.203).

Therefore, at this level the impact of these departments analyzed by focusing on the head of state, the legislative and executive branches and other bureaucratic groups in the foreign policymaking process, and this is according to the nature of the political system in terms of being presidential or parliamentary, that appear or decline by the legal frame of the political system.

\section{The President's Influence as an Institution in Foreign Policymaking}

The head of state is the supreme representative of the state in its foreign relations, he is the one who embodies its sovereignty, and he is the one who expresses the will of the state because it is considered a symbol of it, so international custom and law distinguish it with special privileges and immunities, and the constitution of the state determines and regulates the competences and powers of the head of state in foreign policy, however, there are constitutional regulations that give the head of state broad powers. Therefore, the powers of the head of state must be distinguished between different political and constitutional systems.

In presidential systems, the head of state has a monopoly on directing foreign relations, for example, the president of the USA who directs and manages foreign policy and determines its basic directions, with constitutional, legal, political and judicial mechanisms that limit any excess or default in a way that may show that there is a violation of the law or the constitution. Also, the political system of Russia, so that the Russian president has a lot of broad powers in his relationship with other institutions internally, especially at the level of foreign policy decisions.

The institution of the presidency and its role are influenced by many domestic factors like the influences of the bureaucracy as an institution that influences foreign policy decision-making and consists of government interests and other institutions (Khalil, 1997, pp.80-82).

In parliamentary systems, the head of state has limited powers, often symbolically, honorary or protocol, concerning areas that have no real influence on his country's foreign policy.

The Prime Minister of Spain, the Prime Minister of Italy, or the Chancellor of Germany and Austria play an active role in foreign policy management.

The powers of the president in this type of political system are limited to the accreditation of ambassadors, the acceptance of treaties in cases specified by the constitution, and meeting the heads of other states during their official visits, but he can't intervene in political negotiations with other countries or commits his country to a specific policy, these are the powers of the prime minister, who is the head of the executive branch.

In mixed or semi-presidential systems, which has many characteristics of the parliamentary system, the head of state has broad powers in foreign policy with a margin of movement for the prime minister, the foreign affairs minister, such as: (France, Lebanon, ...).

\section{The Framework of the Domestic Environment for Russian Foreign Policymaking}

Russian foreign policy has known a series of radical transformations, reformulating its foreign policy in a new form of rehabilitation and setting new priorities in its orientations and realistic objectives suitable with the nature of these new transformations that have dealt with the new international order.

Many of the questions were raised asking about the reasons of the transformation of the Russian foreign policy after the end of the cold war, the Russian foreign policy did not know homogeneity and consensus even at this same period after the collapse so that a major shift was observed in the Russian policy towards Europe and in general towards the west between the period of the Russian president Yeltsin and the current President Putin. 


\subsection{The Importance of Internal Variables in Explaining the Transformation in Russian Foreign Policy after the Cold War}

It is necessary to realize that since the collapse of the Soviet Union, Russian foreign policy has undergone many new changes and transformations, such as any country in transition, and it can be said that the Russian economy in 2019 is different from in 2006 and also in 1991, and it can also be said that in 1991, Russia had no clear foreign policy objectives, and it was described as "chaos" (Payne, 2006, p.1).

Russian foreign policy has embarked on a new path since President Putin took office and has begun to emerge from the cycle of stagnation and volatility that characterized it under Yeltsin (Payne, 2006, p.2).

At this level, scholars and researchers began to point out the importance of internal factors and transformations witnessed by Russia in understanding the transformations of its foreign policy, Russian foreign policy did not crystallize its independent objectives during the early years after the collapse of the Soviet Union but appeared with transformations and renaissance that Putin created internally and which reflected on the content of the foreign policy.

So, it was asked what domestic transformations allowed Russia's foreign policy to evolve from Yeltsin's chaos to the new regime set by Putin (Payne, 2006, p.2).

The scholars presented a new and different proposal to understand these transformations, focusing on the process of domestic change to explore this hypothesis that confirms the link between Russia's domestic transformations and the change in its foreign policy path in an acceptable way.

In a lecture entitled "Russia's New Role in International Relations," Russian lecturer Vitaly Naamkin noted that Russian leadership percept Russia's components in the domestic arena like social structure, industrial-technical capabilities and the huge amount of oil and gas, briefly the well-established internal construction is the basis of a powerful state in the international level. China many years ago, as well as Japan, had little regard for the domestic environment and the building of elements of human internal power through science, enlightened culture and the rehabilitation of national competencies in all fields, and now the two countries can establish strong positions at the global level and in foreign policy.

\subsection{Domestic Factors Affecting Russia's Decision-Making Process}

The decision-making process in Russia takes place in a general environment that includes many factors affecting the decision-making process, and includes all the domestic forces influencing the Russian political arena, the most important of which are: the form of the political system that includes the executive branch of the president (government), parliament, as well as the role of the political and intellectual elite, political parties, interest groups, and public opinion, besides the press and the church (Elsheikh, 1998, pp.111-112).

What can be observed is the impact of these factors on internal or external decision-making, with a variable effect of one of them and with no effect of another variable at the level of external decision-making.

9.2.1 The Structure of the Russian Political System and the Position of President in the Decision-Making Process

Russia remained governed by the Constitution of April 12, 1978, even after the collapse of the Soviet Union, until the new constitution was adopted on December 12, 1993, after a referendum.

The system in force in Russia under the 1993 Constitution is presidential, the President of the Russian Federation is the head of state, and the role of parliament is limited and its influence in the decision-making process very narrow.

While the Duma's approval of the president's nomination for prime minister is required, the constitution gives the president the right to reject the president's candidacy for the third time by appointing the prime minister, dissolving the Duma and calling for new elections (Elsheikh, 1998, p.112).

The post of President, which Yeltsin held immediately after the collapse of the Soviet Union, gradually became the dominant institution to such an extent that some feared that Yeltsin had brought in too much power in his hands (Almond, 2010, p.39).

The events experienced by Russia after the collapse of the Soviet Union led to the need to strengthen the executive branch and gradually expand the powers of the president, who was granted broad powers by parliament in November 1991 to help him implement his reform agenda. (Elsheikh, 1998, p.112).

The Russian regime was described as "vertical power', a term devised by the Russian elite to describe a system of governance based on the dominance of the executive (Shevtsova, 2005, p.18). 


\subsubsection{Political Forces Influencing the Foreign Policy Decision-Making Process in Russia}

Political parties in Russia are limited to membership, sometimes as in the Constitutional Democratic Party 300 members, and most of them have no branches or presence throughout Russia.

There are parties couldn't succeed in collecting the minimum number of signatures needed to participate in the elections, so with this number of parties it is difficult to say that there is a party system in the clear sense in Russia, but the United Russia Party is now a very popular party Especially since the support of President Putin.

Interest groups in Russia also do not represent an influential or pressing force on decision-makers, and the most influential and active of these groups are workers who organize in the Union of Independent syndicates, which has 50 million members (Elsheikh, 1998, pp.114-116).

Public opinion For the first time in Russia, the decision-maker takes into account when making decisions, where concern in public opinion polls has begun, and many public opinion polling institutions, which usually publish their polls widely, have appeared in newspapers such as Izvestia, Pravda, and other Russian newspapers and magazines, however, public opinion as an influential force has a limited role, especially in periods of deteriorating economic conditions.

For the Russian press, it has gained a great deal of freedom since Gorbachev came to power and started his reforms, and in mid-1993 the Russian Parliament passed a press law that guarantees its protection, but in practice, the Russian press continues to suffer from many governmental restrictions. It is worth mentioning the activity of Jewish fund in this field and its control over several important newspapers, and even television channels, including the largest private television company NTV owned by Vladimir Gusinsky, the first president of the Russian Jewish National Congress, but the real difficulty facing The Russian press in general is a loss of public confidence in the press.

On the other hand, the Church has begun to restore its spiritual role and active political role since 1987 and has become a source of political legitimacy, and this has been reflected on several occasions, including the presence of Patriarch Alexy II of Moscow, president of the Orthodox Church, at the 1990 Yeltsin inauguration ceremony.

Some Christian movements work in politics, perhaps most notably the Russian Christian Democratic Movement, as well as the fact that some bishops of the Church have a strong relationship with nationalists and conservatives, but there are divisions within the Church, which reduces their impact and its effectiveness at the political and popular levels.

But the most important thing to note is the limited influence and role of these forces as a whole, especially with the phase of the rule of Putin, who tried to focus all the decision-making powers in his hand, to overcome the crises experienced by Russia, which require quick and appropriate decisions.

As for the army and its role in the decision-making process, perhaps here is related to Samuel Huntington's saying in his book Soldiers and State, when he was talking about military interference in politics, he believes that when there is a political vacuum, especially in transition or modernization, the army has an opportunity to intervene in the action.

If we apply this saying to the Russian situation, we can conclude that, despite all the attempts of Yeltsin to fill all the blanks in the Russian political system, this system by its marginalizing parliament and party forces, is experiencing some political vacuum, at a time when Russia is going through a process of transition or to modernize, and from here, according to Huntington's point of view, the Russian military intervening in Russian political life should have increased immediately after the collapse of the Soviet Union, but it is remarkable that this army, particularly in this period of economic decline, suffered from a shortage of supply, as wasn't able to guarantee even $20 \%$ of the nutritional army's needs (Elsheikh, 1998, pp.134-135).

\section{Conclusion}

This paper is mainly interested in providing theoretical scientific value in highlighting the importance of the domestic environment in understanding foreign policy and using them as an analysis tool to understand the reasons for the shifting in Russia's new foreign policy.

After the end of the cold war and as a result of the transformation and improvement of this period, studies in the field of international relations have attempted to present acceptable new concepts and theories to explain the characteristics of the international phenomena and to explore the features of these improvements.

In this context, a series of theories and approaches tried to provide justifications for linking between the inside and the outside and others tried to find the variables affecting the policies of the countries. 
The theoretical debate on the issue of separation and linking between the domestic environment and the foreign policy of countries in terms of effect and result continues, while the realistic approach goes to separate the inside from the outside and deny any impact of the component of the internal environment on the state's external orientation and interests, another team considers the need of linking the domestic environment and foreign policy of states to provide an acceptable and integrated explanation of the transformation in countries' behaviors towards their external environment, similar to the constructivism theory that refuses to separate the domestic and international environment in the analysis of the behavior of political actors. This is evident in the rejection of the classical concept of interest in realistic, the interest stems not only from the nature of the international community but also from the nature of the value and social construction of political units, the interest is no longer determined -as constructivism- outside the social context of actors and in isolation within the international system, as a pregiven dictated by the structure of the chaotic international system.

Russia as a successor of the soviet union who collapsed in front of the western liberal pact, is one of the most important countries that had a dramatic transformation in its foreign policy, distinguished a lot of views in explaining the reasons for transformation towards the west generally and European union especially.

Accordingly, this paper has argued that the study of foreign policy as part of international relations was not isolated from these improvements, as new issues in international relations influenced the content and topics of states foreign policy within the new features of the international system, so there was an urgent need to improve analytical frameworks deal with the improvements to present scientific explanations about factors and variables which affect the transformation of state's foreign policy, especially within the growing interdependence between internal and external issues and its priority.

\section{References}

Adler, I. (1999). Security Communities. Cambridge University Press, New York.

Almond, G. (2010). Comparative politics today: a world view (9th ed.). Longman, New York, NY.

Buzan, B. (2009). The Evolution of International Security Studies. Cambridge University Press, New York. https://doi.org/10.1017/CBO9780511817762

Buzan, B., \& Weaver, O. (2006). The English School of International Relations. Cambridge University Press, New York.

Elsheikh, N. (1998). Decision-making process in Russia and Arab-Russian relations. Al- Mustaqbal Al-Arabi, $20(230)$.

Elsheikh, N. (2000). Ruling elite and foreign policy restructuring: The case of Soviet Union (1985-1991) and Russian Federation (1991-1996). "Doctorate thesis", Cairo University: Faculty of Economics and Political Science.

Evans, G., \& Newnham R. (1998). The Penguin Dictionary of International Relations. Penguin Books, London.

Frankel, J. (1963). The Making of Foreign Policy. Oxford university press, London.

Giddens, A. (2011). Sociology, Polity, London.

Goldmann, K. (1988). Change \& Stability in Foreign Policy: The Problems \& Possibilities of Détente. Princeton University Press, New Jersy, USA. https://doi.org/10.1515/9781400859726

Griffiths, M. (2012). International Relations Theory for 21 century. Routledge, London.

Hatey, N. (1985). Theory in International Relations. Dar AlKitab AlArabi publisher, Beirut.

Hermann, C. (1990). Changing Course: When Governments Choose to Redirect Foreign Policy. International Studies Quarterly, 34(1), 4-5. https://doi.org/10.2307/2600403

Hill, C. (2003). The Changing Politics of Foreign Policy. Palgrave Macmillan.

Holsti, K. (1982). Why Nations Realign: Foreign Policy Restructuring in the Postwar World. George Allen, and Unwin, London.

Huntington, S. (1997). The Erosion of America National Interests. Foreign Affairs, 76, 28. https://doi.org/10.2307/20048198

Jensen, L. (1982). Explaining Foreign Policy. Prentice-Hall, New Jersey.

Khalil, N. (1997). The presidency as a US foreign policy-making institution. Al-Siyasa Al-Dawlia, 32(127).

Linklater, A. et al. (2007). International Relations Theory. Palgrave, London. 
McSweeney, B. (2000). Security, Identity, and Interests: A Sociology of International Relations. Cambridge University, Cambridge.

Mearsheimer, J. (2000). Realism, The Real World and Academia. University of Chicago, USA.

Mingst, K. (2001). Essentials of International Relations. Norton, London.

Mkld, I. (1991). International Political Relations: A Study of Principles and Theories. Academic Bookshop, Cairo. Morgenthau, H. (1985). Politics Among Nations: The Struggle for Power and Peace. Alfred. A. Knopf, New York. Onuf, N. (1998). International Relations in a Constructed World. Sharp, London.

Onuf, N., \& Kubalkouva V. (1998). International Relations in a Constructed World. Sharp, London.

Payne, M. (2006). Behind the Enigma: Changing Internal Factors and Putin's Foreign Policy. Boston University. $\begin{array}{llll}\text { Retrieved } \quad \text { September 22, from } & \text { 2019, }\end{array}$ http://www.bu.edu/ir/graduate/current/papers/samples/Sample_research_paper.pdf

Rosati, J., Hagan, D., \& Sampson, M. (1994). Foreign Policy Restructuring: How Governments Respond to Global Change. University of South Carolina, USA.

Rose, G. (1998). Neoclassical realism and theories of foreign policy. World Politics, 51, 146-149. https://doi.org/10.1017/S0043887100007814

Selim, M. (1998). Foreign Policy Analysis. Alnahda Almasriya publisher, Cairo.

Shevtsova, L. (2005). Putin's Russia. Carnegie Endowment for Int'l Peace, Washington.

Skidmore, D. (1994). Explaining State Responses to International Changes: The Structural Sources of Foreign Policy Rigidity and Change. University of South Carolina, USA.

Viotti, P. (2012). International Relations Theory. Pearson, London.

Viotti, P., \& Kuppi, M. (2011). International Relations Theory. Pearson, London.

Walt, S. (1998). International Relations: One World, Many Theories. Foreign Policy, 110, 29-46. https://doi.org/10.2307/1149275

Wendt, A. (1992). Anarchy What States Make of it. International Organizations, 46(2), 391-425. https://doi.org/10.1017/S0020818300027764

Wendt, A. (1999). Social Theory of International Politics. Cambridge University Press, New York. https://doi.org/10.1017/CBO9780511612183

White, B. (1999). The European Challenge to Foreign Policy Analysis. European Journal of International Relation, 5(5), 37-66. https://doi.org/10.1177/1354066199005001002

Wight, C. (2006). Agent, Structure and International Relations: Politics as Ontology. Cambridge University Press, New York. https://doi.org/10.1017/CBO9780511491764

Yousef, H. (1985). Theory in International Relations. Dar AlKitab AlArabi publisher, Beirut.

\section{Copyrights}

Copyright for this article is retained by the author(s), with first publication rights granted to the journal.

This is an open-access article distributed under the terms and conditions of the Creative Commons Attribution license (http://creativecommons.org/licenses/by/4.0/). 